\title{
Enzymatic Factors in the Sucrose Decline of Sugarcane Desiccated With Paraquat, Diquat, and Dinitro-butylphenol
}

\author{
Alex G. Alexander and Rafael Montalvo-Zapata1
}

\section{INTRODUCTION}

Evidence was presented in a recent paper by the authors of abnormal enzyme behavior and disrupted photosynthesis in sugarcane desiccated with Paraquat ${ }^{2}(16)^{3}$. Two important considerations for the sugar industry were thereby underscored: 1 , The highly desirable effect of cane weight and trash reduction seems possible via chemical desiccation and increased burning efficiency; 2 , undesirable biochemical effects, exemplified by sucrose decline, may nullify the value of the chemical as a desiccant. The fundamental question is whether chemicals can be used with sufficient specificity to retain at least partial photosynthesis while holding sucrose metabolism to $\dot{a}$ minimum. The problem essentially is thus one of selective enzyme control.

It is necessary in approaching the question of enzyme control to define the nature, degree, and sensitivity of enzyme-desiccant relationships. Summarized in the present report are definitive studies of cane enzyme responses to variable Paraquat concentrations. Enzyme studies with Diquat and Dinitrobutylphenol (DNBP) also are evaluated. There were three objectives: 1, To confirm abnormal enzyme and sugar responses to desiccant treatment; 2 , to explore enzyme sensitivity to the dimensions of chemical level and time; 3 , to determine whether a common pattern. of enzyme changes is triggered by the three distinct desiccating agents.

\section{MATERIALS AND METHODS}

\section{GROWTH AND SAMPLING OF PLANT MATERIALS}

Three greenhouse experiments were conducted with plants grown in sand culture as described previously (1). In each instance plants were sprayed once with an aqueous desiccant solution containing Tween 20 as a wetting agent. Solutions were applied until runoff began. Leaf and immature storage tissues were frozen, lyophilized, ground to pass a 60-mesh screen, and stored at $-10^{\circ} \mathrm{C}$. as described earlier (1). Leaf sheaths were re-

1 Plant Physiologist and Assistant Chemist, respectively, Agricultural Experiment Station, Mayagüez Campus, University of Puerto Rico, Río Piedras, P.R.

21,1'dimethyl-4,4-bipyridinium-bis-dimethyl sulfate, commercially known as Gramoxone.

Italic numbers in parentheses refer to Literature Cited, p. 48-9. 
tained for percent-moisture determinations and millable stalks were ground with a small laboratory mill for Brix and polarization analyses.

For experiment 1, 16-week old plants of the variety P.R. 1059 were sprayed with 6 levels of Paraquat. These included 0, 0.0008, 0.004, 0.02, 0.1, and 0.5 percent solutions. Tissue samples were taken at 3 and 6 days after treatment. In experiment 2 the desiccant Diquat ${ }^{4}$ was applied to 6-months old plants of the variety P.R. 980 at levels of 0 and 0.5 percent. Harvests were taken at $0,24,48,72,96,120$, and 144 hours after treatment. For the third experiment $\mathrm{DNBP}^{6}$ was applied to 6-months old plants of the variety P.R. 980. As in experiment 2, treatments were confined to the control and one chemical level, 1.0 percent, the effects of which were studied over a period of 116 hours.

\section{LABORATORY ANALYSFS}

Clarified water extracts of the powdered tissue were analyzed for total ketose by the resorcinol method of Roe (19) and for sucrose by the modification of Cardini et al. (17). Fructose was estimated by subtracting sucrose values from those of total ketose. Total reducing sugars were estimated by the dinitrosalicylic acid method of Sumner (20).

Protein was precipitated from water extracts with solid ammonium sulfate as described previously (1). The 0-80 percent fraction was used for enzyme analyses following 2 hours dialysis against two changes of distilled water. Acid phosphatase and ATP-ase was measured in accordance with methods described earlier (2), as was invertase (3), amylase (4), polyphenol oxidase (9), and peroxidase (8). The technique of Sutherland et al. (21) was used to measure both the water-soluble protein of tissue samples and the protein content of enzyme preparations. Enzyme action was computed as specific activity (activity units per milligram of protein).

Samples of clarified tissue extracts were chromatographed on Whatman no. 1 filter paper using the solvent mixture butanol-pyridine-water $6: 4: 3$ $\nabla / v)$ in one dimension. The water extracts were concentrated by lyophilization prior to application. Reference and unknown sugar spots were developed by the silver nitrate method of Dube and Nordin (18).

Total phosphorus (P) and organic phosphorus (PO) was measured in accordance with procedures described earlier (13). Essentially this involved P analysis of HCl-hydrolyzed and non-hydrolyzed leaf preparations.

Biochemicals were obtained from the Nutritional Biochemicals Corporation, Cleveland, Ohio. Paraquat and Diquat were supplied by local repre-

6,7-dihydrodipyrido $\left(1,2-a: 2^{\prime}, 1^{\prime}\right.$-c)-pyrazidiinium salt, commercially known as "Reglone".

4,6-dinitro-o-sec-butylphenol. 
sentatives of the Chevron Chemical Company, Orthro Division. DNBP was obtained from the Dow Chemical Company, Midland, Michigan.

\section{RESULTS AND DISCUSSION}

\section{EXPERIMENT I. VARIABLE PARAQUAT}

\section{Growth Responses to Paraquat}

Plants were treated about 9:00 a.m. All those receiving Paraquat were visibly wilted by 5 p.m. Foliage had assumed an olive-green color. By 24 hours severe wilting had progressed among plants given 0.1 and 0.5 percent solutions. These appeared to be dead. Spindles among all treatments were tightly curled. By 48 hours a yellow-grey color was replacing the earlier greyish, olive-green appearance of leaves and leaf sheaths. Plants given the

TaBLE 1.-Sheath percent moisture values for immature sugarcane treated with variable Paraquat

\begin{tabular}{c|c|c|c|c|c|c|c}
\hline \multirow{2}{*}{$\begin{array}{c}\text { Days after } \\
\text { treatment }\end{array}$} & \multicolumn{6}{|c|}{ Paraquat (percent solution) } & \multirow{2}{*}{$\begin{array}{c}\text { Paraquat } \\
\text { mean }\end{array}$} \\
\cline { 2 - 6 } & 0 & 0.0008 & 0.004 & 0.02 & 0.10 & 0.50 & \\
\hline 3 & 81.1 & 83.6 & 81.1 & 82.0 & 78.0 & 64.3 & 77.9 \\
6 & 80.6 & 74.6 & 74.3 & 74.7 & 57.1 & 40.2 & 64.1 \\
\hline Mean & 80.9 & 79.1 & 77.7 & 78.4 & 67.8 & 52.3 & \\
\hline
\end{tabular}

two highest Paraquat treatments obviously were dead. Those receiving lesser amounts survived and gradually produced new foliage in inverse proportion to desiccant level.

Curiously, the visible wilting of leaf blades was not clearly reflected by sheath-moisture values at any but the highest Paraquat level, at 3 days, and only in the two highest levels at 6 days (table 1). Stalks were not appreciably desiccated. A grower viewing similar leaf symptoms in the field might easily overestimate the amount of actual drying.

\section{Sugar Responses}

Leaf sucrose declined sharply in all plants treated with Paraquat (table 2). Even those given only an 0.0008 percent solution showed a 50-percent decline within 3 days, and still greater losses at 6 days. This verifies earlier results for Paraquat applied to P.R. 980 (16).

An interesting feature was the ability of high-Paraquat plants to retain more sucrose than those given lesser amounts (fig. 1). This, in fact, supports the authors' theory that sugar metabolism proceeds in desiccating leaves 
after photosynthesis has been blocked (16). In this instance high Paraquat may have destroyed both photosynthetic and metabolic capability by killing the plants, whereas lower Paraquat permitted metabolism to continue

TABLE 2.-Leaf-sugar content of immature sugarcane treated with Paraguat

\begin{tabular}{|c|c|c|c|c|c|c|c|c|}
\hline \multirow{2}{*}{ Sugar (m8./g. of dry wt.) } & \multirow{2}{*}{$\begin{array}{l}\text { Days after } \\
\text { treatment }\end{array}$} & \multicolumn{6}{|c|}{ Paraquat (percent solution) } & \multirow{2}{*}{$\begin{array}{c}\text { Parequat } \\
\text { mean }\end{array}$} \\
\hline & & 0 & 0.0008 & 0.004 & 0.02 & 0.1 & 0.5 & \\
\hline Total ketose & $\begin{array}{l}3 \\
6\end{array}$ & $\begin{array}{l}72.1 \\
66.8\end{array}$ & $\begin{array}{l}39.5 \\
19.7\end{array}$ & $\begin{array}{l}25.6 \\
18.0\end{array}$ & $\begin{array}{l}24.8 \\
19.2\end{array}$ & $\begin{array}{l}35.7 \\
31.3\end{array}$ & $\begin{array}{l}65.9 \\
58.0\end{array}$ & $\begin{array}{l}38.3 \\
29.2\end{array}$ \\
\hline Sucrose & $\begin{array}{l}3 \\
6\end{array}$ & $\begin{array}{l}70.4 \\
65.8\end{array}$ & $\begin{array}{l}34.7 \\
15.8\end{array}$ & $\begin{array}{r}17.2 \\
7.3\end{array}$ & $\begin{array}{r}13.8 \\
6.2\end{array}$ & $\begin{array}{l}18.8 \\
13.8\end{array}$ & $\begin{array}{l}43.1 \\
33.0\end{array}$ & $\begin{array}{l}25.5 \\
15.2\end{array}$ \\
\hline Fructose & $\begin{array}{l}3 \\
6\end{array}$ & $\begin{array}{l}1.7 \\
1.0\end{array}$ & $\begin{array}{l}4.8 \\
3.9\end{array}$ & $\begin{array}{r}8.4 \\
10.7\end{array}$ & $\begin{array}{l}11.0 \\
13.0\end{array}$ & $\begin{array}{l}16.9 \\
17.5\end{array}$ & $\begin{array}{l}22.8 \\
25.0\end{array}$ & $\begin{array}{l}12.8 \\
14.0\end{array}$ \\
\hline $\begin{array}{l}\text { Total reducing sug- } \\
\text { ars }\end{array}$ & $\begin{array}{l}3 \\
6\end{array}$ & $\begin{array}{r}12.0 \\
9.8\end{array}$ & $\begin{array}{l}8.2 \\
7.4\end{array}$ & $\begin{array}{l}12.4 \\
10.2\end{array}$ & $\begin{array}{l}14.5 \\
11.3\end{array}$ & $\begin{array}{l}24.0 \\
13.4\end{array}$ & $\begin{array}{l}37.6 \\
18.8\end{array}$ & $\begin{array}{l}19.3 \\
12.2\end{array}$ \\
\hline
\end{tabular}

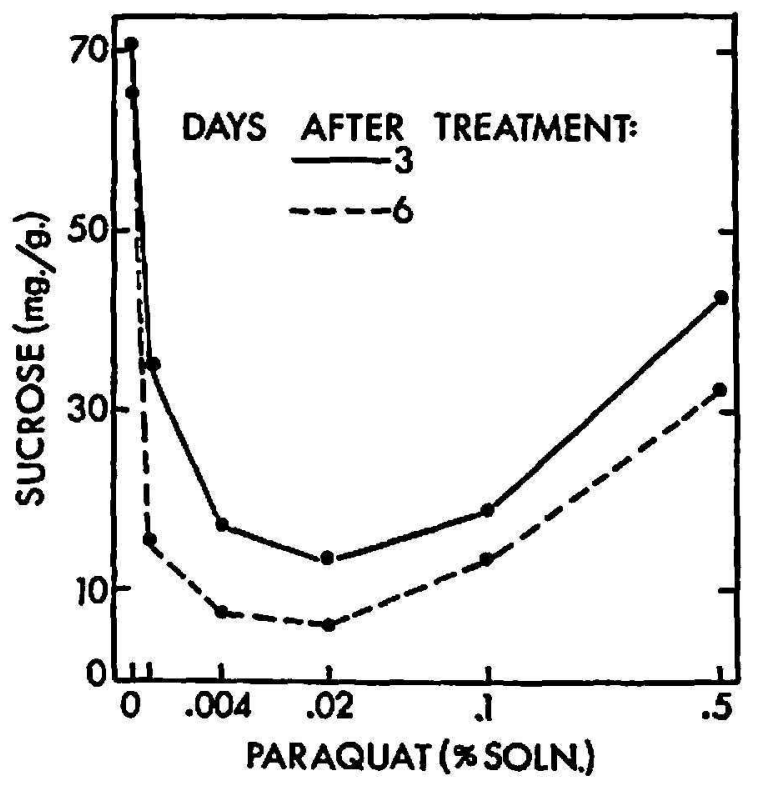

FIG. 1.-Sucrose decline in sugarcane leaves sprayed with low concentrations of Paraquat, and partial retention of sucrose in leaves receiving greater amounts of Paraquat.

after photosynthesis had stopped. Thus, from the standpoint of both greater drying and better sugar retention, one might logically try to kill the plant with high desiccant treatments rather than to wilt it with lesser amounts. This view is not accepted by the authors. By judicious enzyme control, it should be possible to wilt foliage, to maintain some photosynthesis and to 
retard metabolism, thereby gaining a major objective of desiccation while retaining sucrose rather than losing it.

Earlier work revealed that ribose appears in sugarcane leaves within 48 hours after treatment with 0.5 percent Paraquat (16). This apparently reflects a blocking of the photosynthetic conversion of ribose phosphate to ribulose phosphate, and implies specific interference with the enzyme phosphoribose isomerase:

\section{Phosphoribose \\ RIBOSE-5-PHOSPHATE $\stackrel{\text { isomerase }}{\longrightarrow}$ RIBULOSE-5-PHOSPHATE}

Ribose-5-phosphatase action then would yield free ribose.

The appearance of ribose thus constitutes an indicator of the time and biochemical position of photosynthetic disruption. During the present study we were concerned with the sensitivity of this indicator to specific Paraquat levels. The paper chromatogram illustrated by figure 2 shows that, at 3 days after treatment, ribose appeared in response to as little as 0.004 percent Paraquat. This is considerably a more sensitive measure of desiccant action than sheath percent moisture, the latter requiring 0.1 percent Paraquat to effect even a trace of sheath drying at 3 days (table 1 ). It also is evident that 0.0008 percent Paraquat, which caused visible wilting, did not yield detectable ribose. This suggests quite significantly that photosynthesis can proceed in wilting leaves up to some critical point of desiccant level.

Figure 2 also verifies the initial loss and then partial retention of sucrose with increasing Paraquat concentrations. The appearance of several sugars of lesser mobility than raffinose is likewise confirmed. These were observed previously (16) and are believed to contain sucrose linkages which have accepted hexose residues during transferase reactions (11). Careful study of figure 2 supports this thesis in that the rare sugars first increase and then decline within the same Paraquat series which first decreases and later increases sucrose. Silicon is the only agent known at this laboratory to alter in vitro interconversions of sucrose (15). The capacity of Paraquat to do this within living tissues helps explain suppression of sucrose yield by this chemical.

\section{Enzyme responses}

On the basis of earlier findings with P.R. 980, two major enzyme-Paraquat relationships awaited confirmation and scrutiny under conditions of graduated desiccant level: 1, Major increase of amylase action, making possible the rapid breakdown of sucrose after photosynthesis has ceased; and 2, severe invertase suppression, exemplifying the ultimate potential of Paraquat as a ripening agent. 
Leaf amylase in fact was stimulated by 0.5 percent Paraquat (table 3), the same concentration effective on P.R. 980 (16), but no other Paraquat level appreciably altered the leaf amylase behavior. However, amylase of

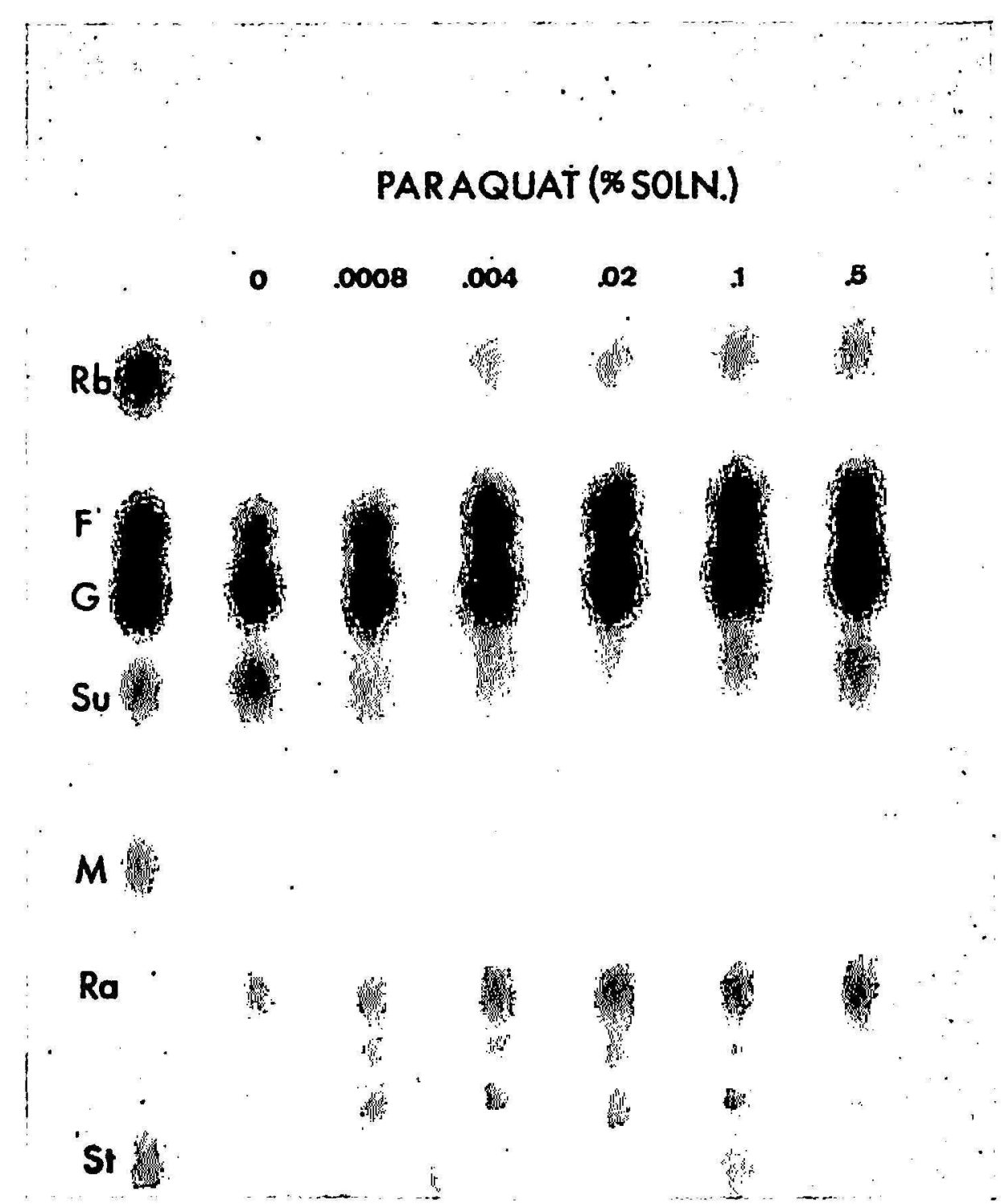

FIg. 2.-Appearance of ribose in extracts of cane leaves sprayed with increasing levels of Paraquat. The letters Rb, F, G and Su identify anthentic ribose, fructose, glucose and sucrose, respectively.

immature storage tissue was markedly increased by all Paraquat treatments (table 4). Since amylase was most affected in leaves of P.R. 980 (16) the question of varietal response is raised. More specifically it is a question of desiccant translocation from leaf to storage tissues. Here such factors as time of day applied, light intensity, water supply and general plant vigor must all be taken into account.

Invertase clearly was suppressed by Paraquat (table 4). At 3 days only 
TABle 3.-Specific-activily values for leaf enzymes of sugarcane treated with Paraqual

\begin{tabular}{|c|c|c|c|c|c|c|c|c|}
\hline \multirow{2}{*}{ Enzyme } & \multirow{2}{*}{$\begin{array}{l}\text { Days after } \\
\text { treatment }\end{array}$} & \multicolumn{6}{|c|}{ Paraquat (percent solution) } & \multirow{2}{*}{ Paraquat mean } \\
\hline & & 0 & 0.0008 & 0.004 & 0.02 & 0.1 & 0.5 & \\
\hline \multirow[t]{2}{*}{ Phosphatase } & 3 & 14.7 & 26.6 & 20.0 & 20.8 & 18.5 & 12.2 & 19.6 \\
\hline & 6 & 12.8 & 14.4 & 14.0 & 13.2 & 11.4 & 13.5 & 13.3 \\
\hline \multirow[t]{2}{*}{ ATP-ase } & 3 & 17.9 & 27.4 & 19.7 & 21.5 & 19.6 & 13.6 & 20.4 \\
\hline & 6 & 16.1 & 15.2 & 13.5 & 11.8 & 10.2 & 11.2 & 12.4 \\
\hline \multirow[t]{2}{*}{ Amylase } & 3 & 40.4 & 42.9 & 46.0 & 41.4 & 42.9 & 53.5 & 45.3 \\
\hline & 6 & 34.6 & 26.5 & 27.1 & 31.0 & 40.0 & 50.6 & 35.0 \\
\hline \multirow[t]{2}{*}{ Peroxidase } & 3 & 126 & 91 & 67 & 61 & 75 & 45 & 68 \\
\hline & 6 & 99 & 43 & 24 & 21 & 13 & 14 & 23 \\
\hline \multirow[t]{2}{*}{ Tyrosinase } & 3 & 10.2 & 14.0 & 11.6 & 12.0 & 14.0 & 10.6 & 12.4 \\
\hline & 6 & 7.8 & 8.5 & 6.0 & 5.6 & 2.5 & 1.0 & 4.7 \\
\hline
\end{tabular}

TADLE 4.-Specific-aclivily values for enzymes of immalure slorage tissue from sugarcane sprayed with Paraquat

\begin{tabular}{|c|c|c|c|c|c|c|c|c|}
\hline \multirow{2}{*}{ Enzyme } & \multirow{2}{*}{$\begin{array}{l}\text { Days after } \\
\text { treatment }\end{array}$} & \multicolumn{6}{|c|}{ Paraquat (percent solution) } & \multirow{2}{*}{$\begin{array}{c}\text { Paraquat } \\
\text { mean }\end{array}$} \\
\hline & & 0 & 0.0008 & 0.004 & 0.02 & 0.1 & 0.5 & \\
\hline \multirow[t]{2}{*}{ Phosphatase } & 3 & 32 & 31 & 29 & 34 & 25 & 23 & 29 \\
\hline & 6 & 32 & 50 & 40 & 43 & 38 & 26 & 39 \\
\hline \multirow[t]{2}{*}{ ATP-ase } & 3 & 33 & 32 & 29 & 34 & 27 & 27 & 30 \\
\hline & 6 & 33 & 52 & 48 & 42 & 40 & 28 & 42 \\
\hline \multirow[t]{2}{*}{ Amylase } & 3 & 56 & 78 & 81 & 85 & 62 & 77 & 77 \\
\hline & 6 & 87 & 148 & 145 & 108 & 162 & 126 & 138 \\
\hline \multirow[t]{2}{*}{ Invertase } & 3 & 5.7 & 5.4 & 4.5 & 5.8 & 3.9 & 0.2 & 3.8 \\
\hline & 6 & 8.2 & 12.6 & 1.9 & 4.0 & 0.2 & 0.1 & 3.8 \\
\hline \multirow[t]{2}{*}{ Peroxidase } & 3 & 43 & 51 & 48 & 51 & 44 & 30 & 45 \\
\hline & 6 & 48 & 44 & 46 & 45 & 59 & 53 & 49 \\
\hline \multirow[t]{2}{*}{ Tyrosinase } & 3 & 14 & 14 & 13 & 14 & 11 & 12 & 13 \\
\hline & 6 & 11 & 22 & 19 & 24 & 19 & 16 & 20 \\
\hline
\end{tabular}


the 0.1 and 0.5 percent levels affected invertise, but at 6 days as little as 0.004 percent had severely retarded the enzyme. Since invertase is confined largely to storage tissues, the translocation of desiccant from leaves to the site of enzyme action again becomes a major issue in determining the most effective chemical level for inversion control.

While the previously-recorded effects of Paraquat upon amylase and invertase are confirmed by the present study, a newly-recognized response was the severe inhibition of leaf peroxidase (table 3). Leaf tyrosinase also was curtailed but only by the higher Paraquat levels and only at 6 days (table 3). Similar effects were actually recorded during the previous study but were given scant attention since they were confined to a single harvest taken 168 hours after treatment. Oxidase suppression was then regarded as a result rather than cause of the tissue's death, i.e., rather than a direct desiccant-enzyme relationship. It now appears that peroxidase can be altered dramatically by as little as 0.0008 percent Paraquat-a quantity which wilts leaves but apparently does not disrupt photosynthesis or remotely approach a level lethal to the plant.

\section{EXPERIMENT II. DIQUAT $\times$ TMME}

\section{Growth responses to Diquat}

Symptoms of Diquat injury were indistinguishable from those described for Paraquat. Treatments were applied at 8:30 a.m. on a clear, hot day and by 3:30 p.m. the Diquat plants were wilted and discolored. At 24 hours the foliage was severely desiccated. By 36 hours the leaves were dry, very tightly rolled, and were assuming a brownish discoloration. Sheaths were beginning to desiccate. The following morning, at 48 hours, no green leaf or sheath tissue remained. Stalks appeared to lose some turgidity by 72 hours.

As was true of the Paraquat-treated cane, the early desiccation of leaves was not reflected by sheath-percent moisture values. A measurable decline of total fresh weight had begun by 24 hours (fig. 3, A), but loss of sheath moisture could not be claimed reliably prior to 96 hours (fig. $3, \mathrm{~B}$ ).

\section{Sugar responses to Diquat}

The Diquat foliar sprays led to leaf sucrose decline which was easily detected at 24 hours (fig. $4, \mathrm{~A}$ ). This loss of sucrose was initially abrupt but the level remained generally constant thereafter. Reducing sugar content rose progressively with time. The reducing sugars do not reflect sucrose inversion since invertase is almost non-existent in leaves. The presence of ribose in leaf extracts, revealed by paper chromatography, suggests that Diquat impaired the photosynthetic conversion of ribose-5-phosphate to ribulose-5phosphate, a function already credited to Paraquat (16). 
Sucrose losses from juice of millable stalks were recorded at 96 hours and these losses became very severe by 144 hours (fig. 4, B). Sucrose failed to decline in immature storage tissue until after the 96-hour harvest; in fact, some moderate increases were observed up to this period (table 5). A similar effect was noted earlier for Paraquat (16) and probably is accountable

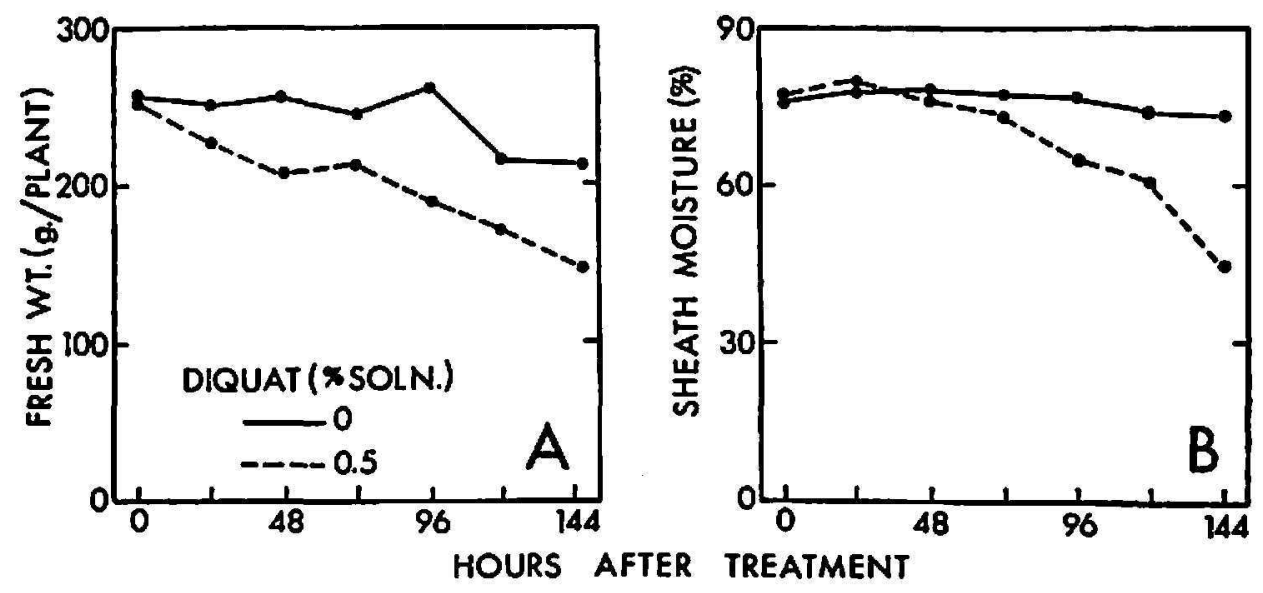

FIG. 3.-Growth responses of sugarcane to foliar treatment with Diquat: A, Total fresh weight; $B$, Sheath percent moisture.

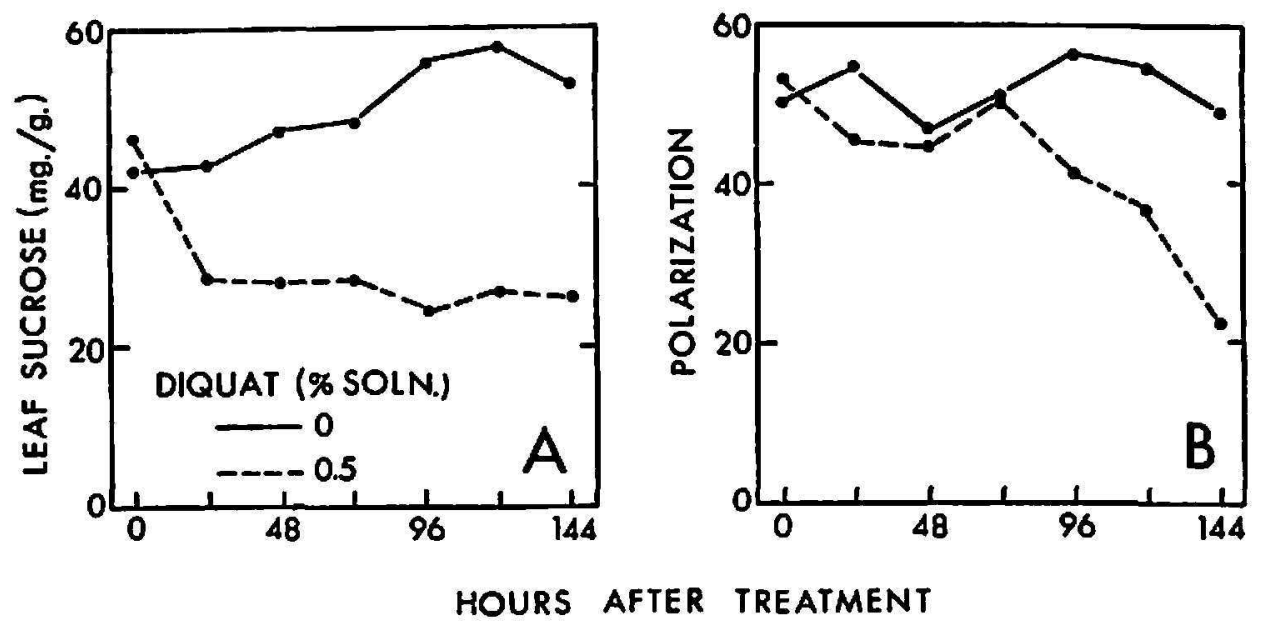

Fie. 4. Sugar changes in sugarcane desiceated with Diquat: A, Leaf sucrose decline; B, Polarization decline for juice of millable stalks.

to a severe suppression of invertase by the desiccant (see invertase under "Enzyme Responses to Diquat").

Sugar effects of Diquat seem virtually identical to those of Paraquat. The practical implication here again is that, to desiccate with an enzymatically non-specific chemical, a price must be paid in lost sucrose.

\section{Enzyme responses to Diquat}

The sensitivity of invertase, amylase, and peroxidase to Paraquat, which already has been discussed, was partially affirmed by Diquat during the 
TaBLs 5.-Sugar responses of immature sugarcane treated with Diguat ${ }^{2}$

\begin{tabular}{|c|c|c|c|c|c|c|c|c|c|c|}
\hline \multirow{2}{*}{ Tissue } & \multirow{2}{*}{ Data class? } & \multirow{2}{*}{$\begin{array}{l}\text { Diquat } \\
\text { (percent } \\
\text { solution) }\end{array}$} & \multicolumn{7}{|c|}{ Hours after treatment } & \multirow{2}{*}{ Mean } \\
\hline & & & 0 & 24 & 48 & 72 & 96 & 120 & 144 & \\
\hline \multirow[t]{4}{*}{ Leaf } & Sucrose & 0 & 42.1 & 42.5 & 47.5 & 48.1 & 56.3 & 57.5 & 52.8 & 49.6 \\
\hline & & 0.5 & 46.9 & 28.8 & 28.2 & 28.6 & 22.7 & 27.8 & 26.6 & 29.9 \\
\hline & Reducing & 0 & 10.2 & 11.1 & 9.9 & 10.4 & 11.2 & 10.5 & 10.3 & 10.5 \\
\hline & sugars & 0.5 & 10.4 & 10.7 & 15.0 & 16.8 & 20.3 & 23.1 & 24.3 & 17.2 \\
\hline \multirow{4}{*}{$\begin{array}{c}\text { Immature } \\
\text { storage }\end{array}$} & Sucrose & $\mathbf{0}$ & 69.1 & 73.0 & 71.1 & 71.7 & 77.2 & 84.2 & 71.7 & 74.0 \\
\hline & & 0.5 & 68.2 & 83.6 & 81.4 & 97.3 & 81.7 & 67.8 & 67.9 & 78.3 \\
\hline & Reducing & 0 & 57.1 & 59.9 & 57.1 & 61.8 & 61.1 & 57.8 & 55.1 & 58.6 \\
\hline & sugars & 0.5 & 54.9 & 52.0 & 49.7 & 51.1 & 46.1 & $\mathbf{4 0 . 0}$ & 42.9 & 48.1 \\
\hline \multirow[t]{4}{*}{ Stalk } & Brix & 0 & 19.0 & 15.7 & 13.9 & 15.3 & 16.5 & 15.2 & 13.9 & 15.6 \\
\hline & & 0.5 & 18.0 & 13.1 & 13.5 & 14.8 & 12.8 & 11.5 & 9.5 & 13.3 \\
\hline & Pol. & 0 & 70.2 & 54.8 & 47.2 & 51.9 & 56.9 & 54.6 & 48.9 & 54.9 \\
\hline & & 0.5 & 63.8 & 45.3 & 45.1 & 50.6 & 41.8 & 37.2 & 22.5 & 43.8 \\
\hline
\end{tabular}

1 Each figure represents the computed mean of two replicates.

2 Total ketose, sucrose, and reducing-sugar values are expressed as milligrams per gram of dry weight.

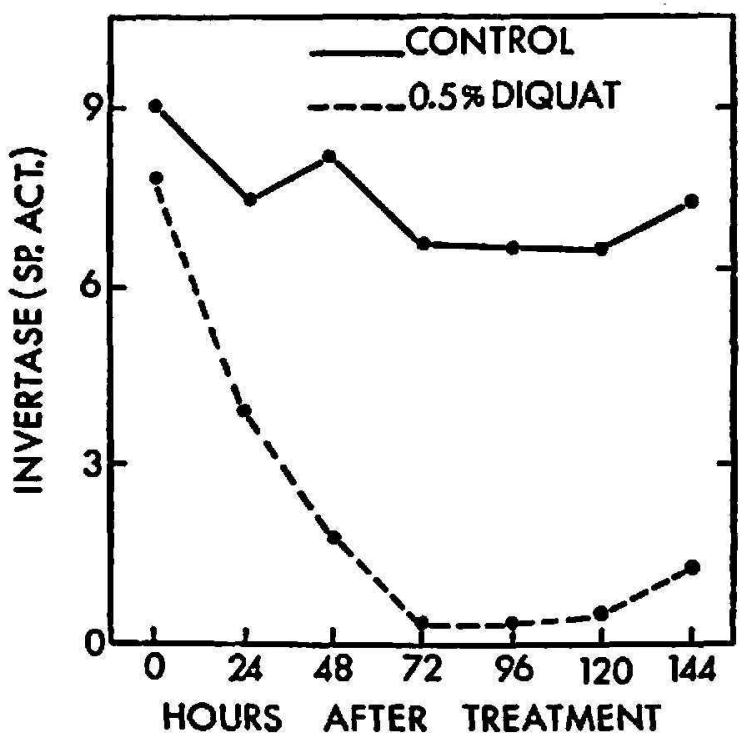

FiG. 5.-Invertase decline in immature storage tissue of sugarcane treated with Diquat.

present experiment. Invertase was very clearly suppressed (fig. 5, table 6). The loss of inversion capability was of such magnitude and persistence that one wonders whether a ripening role might not be possible for this material. The problem again is one of controlling undesirable enzymatic reactions, 
TABLE 6.-Mean specific-activity values for meristem enzymes of immature sugarcane treated with Diquat

\begin{tabular}{|c|c|c|c|c|c|c|c|c|c|}
\hline \multirow{2}{*}{ Enzyme } & \multirow{2}{*}{$\begin{array}{l}\text { Diquat } \\
\text { (percent } \\
\text { solution) }\end{array}$} & \multicolumn{7}{|c|}{ Hours after treatment } & \multirow{2}{*}{ Mean } \\
\hline & & 0 & 24 & 48 & 72 & 96 & 120 & 144 & \\
\hline \multirow[t]{2}{*}{ Phosphatase } & $\mathbf{0}$ & 7.4 & 8.2 & 8.7 & 6.9 & 6.9 & 5.7 & 7.3 & 7.3 \\
\hline & 0.5 & 8.7 & 5.4 & 8.2 & 9.4 & 8.1 & 9.7 & 10.8 & 8.6 \\
\hline \multirow[t]{2}{*}{ ATP-ase } & 0 & 12.7 & 13.1 & 14.8 & 10.5 & 11.1 & 8.2 & 12.9 & 11.9 \\
\hline & 0.5 & 15.2 & 9.9 & 13.8 & 14.9 & 12.4 & 14.8 & 16.1 & 13.7 \\
\hline \multirow[t]{2}{*}{ Amylase } & 0 & 18.2 & 14.7 & 15.9 & 10.1 & 13.2 & 11.5 & 14.4 & 13.9 \\
\hline & 0.5 & 15.5 & 17.9 & 16.7 & 20.3 & 22.2 & 8.9 & 23.7 & 19.3 \\
\hline \multirow[t]{2}{*}{ Invertase } & $\mathbf{0}$ & 9.1 & 7.5 & 8.3 & 6.7 & 6.6 & 6.6 & 7.5 & 7.5 \\
\hline & 0.5 & 7.7 & 4.0 & 1.8 & 0.3 & 0.3 & 0.5 & 1.3 & 2.3 \\
\hline \multirow[t]{2}{*}{ Peroxidase } & 0 & 11.3 & 10.9 & 13.4 & 8.4 & 8.1 & 8.4 & 9.9 & 10.1 \\
\hline & 0.5 & 10.2 & 8.2 & 16.8 & 19.0 & 24.1 & 21.8 & 27.1 & 18.2 \\
\hline
\end{tabular}

1 Each figure represents the computed mean of two replicates.

TABLD 7.-Mean specific-activity values for leaf enzymes of immature sugarcane treated with Diquat ${ }^{1}$

\begin{tabular}{|c|c|c|c|c|c|c|c|c|c|}
\hline \multirow{2}{*}{ Enzyme } & \multirow{2}{*}{$\begin{array}{l}\text { Diquat } \\
\text { (percent } \\
\text { solution) }\end{array}$} & \multicolumn{7}{|c|}{ Hours after treatment } & \multirow{2}{*}{ Mean } \\
\hline & & 0 & 24 & 48 & 72 & 96 & 120 & 144 & \\
\hline \multirow[t]{2}{*}{ Phosphatase } & 0 : & 9.3 & 10.9 & 8.9 & 8.3 & 7.8 & 9.2 & 9.1 & 9.1 \\
\hline & 0.5 & 10.8 & 5.8 & 4.6 & 4.3 & 3.5 & 4.0 & 3.7 & 5.2 \\
\hline \multirow[t]{2}{*}{ ATP-ase } & 0 & 10.5 & 13.7 & 11.2 & 10.4 & 9.3 & 10.2 & 10.0 & 10.8 \\
\hline & 0.5 & 9.8 & 6.4 & 6.3 & 4.9 & 3.6 & 3.7 & $\mathbf{3 . 2}$ & 6.4 \\
\hline \multirow[t]{2}{*}{ Amylase } & 0 & 25.0 & 29.8 & 27.1 & 20.1 & 23.2 & 24.5 & 23.5 & 25.6 \\
\hline & 0.5 & 26.5 & 27.4 & 27.4 & 32.9 & $28: 7$ & 25.4 & 25.2 & 27.6 \\
\hline \multirow[t]{2}{*}{ Peroxidase } & 0 & 42.2 & 40.3 & 50.2 & 33.2 & 40.7 & 46.9 & 36.8 & 41.5 \\
\hline & 0.5 & 36.0 & 32.8 & 41.6 & 50.9 & 55.9 & 35.0 & 40.8 & 41.9 \\
\hline
\end{tabular}

1 Each figure represents the computed mean of two replicates.

which proceed concurrently with desirable ones, or of developing a chemical with greater specificity of action.

Amylase was not affected by Diquat in leaves (table 7). Some amylase stimulation was recorded in immature storage tissue (table 6), but the effect was not evident before 72 hours, as compared to 24 hours for Paraquat (16). 
Peroxidase in storage tissue was very clearly increased by Diquat (fig. 6). This contrasts with leaf peroxidase suppression by Paraquat.

One limitation of the Paraquat-Diquat comparisons is that while the former study involved many Paraquat levels at only 2 time intervals, the latter experiment concerns only two Diquat levels during many intervals of time. It is significant that the same three enzymes show sensitivity to both desiccants, albeit only invertase behaved identically within the dimensions of time and desiccant concentration.

Phosphatase and ATP-ase were severely suppressed by Diquat in leaves (table 7). These enzymes assume important roles in catalyzing the hydrolysis of numerous organic phosphates and ATP. Significance of their chang-

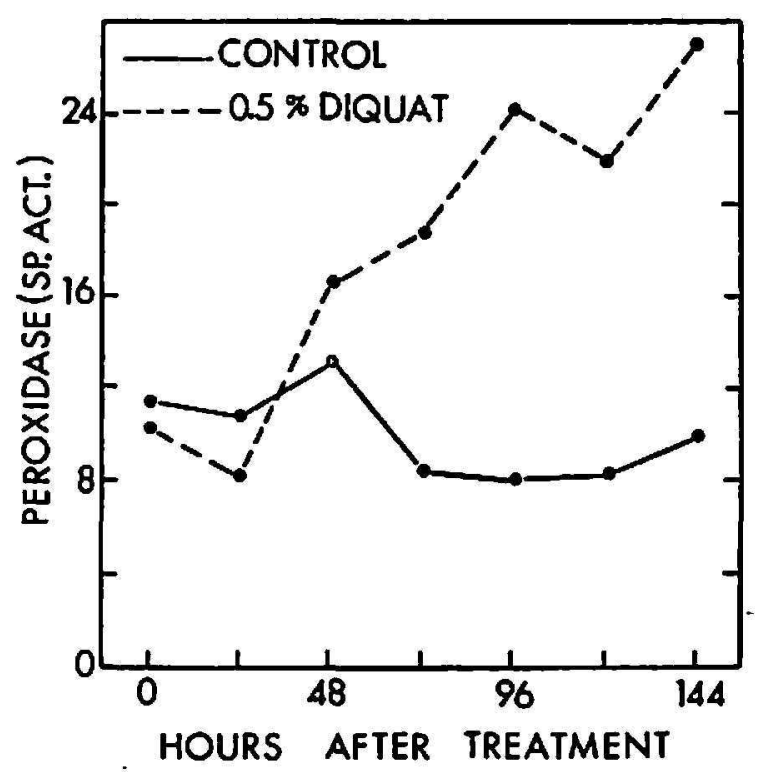

FIG. 6.-Increased peroxidase activity in immature storage tissue of sugarcane treated with Diquat.

ing work potential in cane has been discussed previously at length $(1,2,7)$. Figure 7 illustrates that, during the present study, phosphatase suppression was accompanied by striking and persistent increases in leaf organic phosphorus (PO). This fraction presumably includes high-energy phosphates and phosphorylated intermediates of photosynthesis.

\section{EXPERIMENT III. DNBP $X$ TIME}

Growth effects of DNBP

As in the case of Diquat, a single DNBP level was studied during an extended period of time. The 1.0 percent "solution" was applied at 10:00 a.m. on a clear day and by 6:00 p.m. the DNBP plants displayed injury symptoms. These included severe browning and curling of foliage, and occasional lodging of stalks. Within 24 hours there was general physical weak- 
ening of treated plants as exemplified by drooping foliage and flaccid, often lodging, stalks. Meristem and immature storage tissue became black and progressively shrunken.

Sheath-moisture values began to decline between 24 and 36 hours (table 8). However, these losses were not particularly severe prior to the 78-hour harvest. Even after 3 days the leaves and sheaths, obviously shriveled and dead, were "clamy" to the touch and not clearly dried in the sense achieved with Paraquat and Diquat.
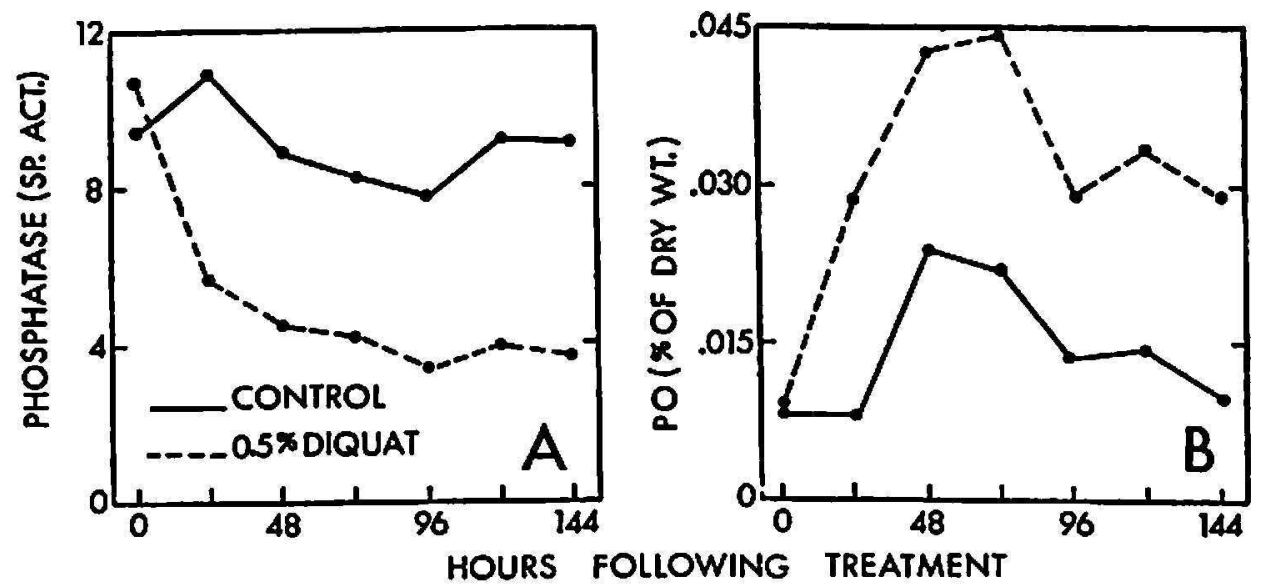

Fra. 7.-Effects of Diquat on phosphatase and organic phosphorus content of sugarcane leaves: A, Phosphatase decline; B, Increase of PO.

TABLE 8.-Sheath-percent moisture for immature sugarcane treated with DNBP

\begin{tabular}{c|c|c|c|c|c|c|c|c|}
\hline \multirow{2}{*}{$\begin{array}{c}\text { DNBP (percent } \\
\text { solution) }\end{array}$} & \multicolumn{7}{|c|}{ Hours after treatment } & \multirow{2}{*}{ Mean } \\
\cline { 2 - 6 } & 0 & 8 & 24 & 36 & 48 & 78 & 116 & \\
\hline 0 & 77.4 & 79.9 & 79.7 & 79.4 & 80.8 & 79.5 & 79.0 & 79.4 \\
1.0 & 77.5 & 80.5 & 78.8 & 75.5 & 73.6 & 57.2 & 47.7 & 70.1 \\
\hline
\end{tabular}

1 Each figure represents the computed mean of two replicates.

\section{Sugar effects of $D N B P$}

Foliar DNBP quickly lowered leaf sucrose content (table 9). This loss was already occurring by 8 hours and progressed in severity throughout the study. Simultaneously the content of leaf reducing sugar was vastly increased (fig. 8). Paper chromatography verified heavy increases of both glucose and fructose in DNBP-treated leaves. No evidence of ribose was detected, however, which suggests that the interruption of photosynthesis took place at a different site than that noted for Paraquat and Diquat.

The rise in reducing sugar values is not clearly accounted for. Simple inversion of sucrose is ruled out for lack of sufficient invertase in leaf tissues. 
One possibility is that the glucose end of sucrose was attacked by amylase acting as an alpha-glucosidase. More likely, the photosynthetic reactions were halted short of sucrose synthesis. This question could be resolved by subjecting DNBP-treated plants to a ${ }^{14} \mathrm{C}$ labeled-CO $\mathrm{CO}_{2}$ atmosphere. The appearance of ${ }^{14} \mathrm{C}$ in sucrose prior to its detection in the accumulated reducing sugars would give strong support for an amylase role in leaf sucrose metabolism.

TABLE 9.-Leaf sucrose content of sugarcane sprayed with DNBP1

\begin{tabular}{c|c|c|c|c|c|c|c|c|c}
\hline \multirow{2}{*}{$\begin{array}{c}\text { Sugar (m8./8. } \\
\text { of dry wt.) }\end{array}$} & $\begin{array}{c}\text { DNBP (per- } \\
\text { cent solution) }\end{array}$ & \multicolumn{6}{|c|}{ Hours after treatment } & Mean \\
\cline { 2 - 7 } & & 0 & 8 & 24 & 36 & 18 & 78 & 116 & \\
\hline \multirow{2}{*}{ Sucrose } & 0 & 33.6 & 52.3 & 42.5 & 59.5 & 44.8 & 73.5 & 62.9 & 52.7 \\
& 1.0 & 37.8 & 26.8 & 24.3 & 19.6 & 20.2 & 13.3 & 9.6 & 21.7 \\
\hline
\end{tabular}

1 Each figure represents the computed mean of two replicates.

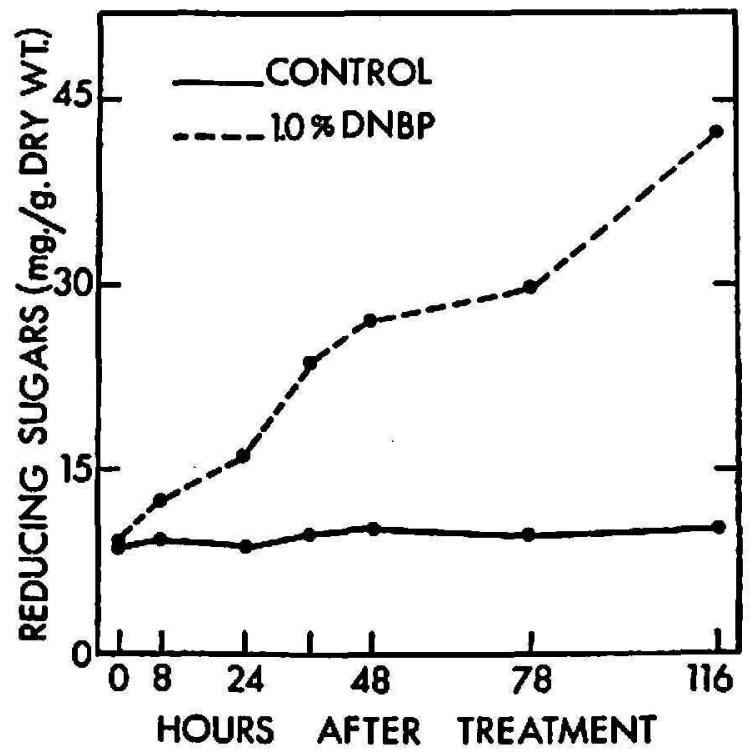

Fia. 8.-Increased reducing sugar content of sugarcane leaves sprayed with DNBP.

Sugars of immature storage tissue reflect a general restriction of synthesis and translocation by DNBP (table 10). Total ketose content declined, as did that of sucrose, fructose, and reducing sugars. The sucrose losses occurred in spite of severe invertase inhibition (see invertase under "Enzyme Responses to DNBP").

\section{Enzyme responses to $D N B P$}

Invertase was very quickly and severely altered by the foliar treatment. Within 8 hours DNBP had lowered invertase activity to an insignificant 
level (fig. 9, table 11), and after 24 hours the enzyme was almost undetectable. Invertase suppression is thus a common response to Paraquat, Diquat and DNBP. The speed of invertase inhibition is evidence of quick DNBP

TABLE 10,-Sugar content of immature storage tissue from sugarcane sprayed with DNBP 1

\begin{tabular}{|c|c|c|c|c|c|c|c|c|c|}
\hline \multirow{2}{*}{ Sugar (mg/g.) } & \multirow{2}{*}{$\begin{array}{l}\text { DNBP } \\
\text { (percent } \\
\text { solution) }\end{array}$} & \multicolumn{7}{|c|}{ Hours after treatment } & \multirow{2}{*}{ Mean } \\
\hline & & 0 & 8 & 24 & 36 & 48 & 78 & 116 & \\
\hline Total ketose & $\begin{array}{l}0 \\
1.0\end{array}$ & $\begin{array}{l}178 \\
226\end{array}$ & $\begin{array}{l}188 \\
142\end{array}$ & $\begin{array}{l}228 \\
109\end{array}$ & $\begin{array}{l}216 \\
106\end{array}$ & $\begin{array}{l}233 \\
105\end{array}$ & $\begin{array}{l}253 \\
100\end{array}$ & $\begin{array}{r}269 \\
47\end{array}$ & $\begin{array}{l}224 \\
119\end{array}$ \\
\hline Sucrose & $\begin{array}{l}0 \\
1.0\end{array}$ & $\begin{array}{l}44.6 \\
51.6\end{array}$ & $\begin{array}{l}73.5 \\
37.7\end{array}$ & $\begin{array}{l}44.3 \\
21.8\end{array}$ & $\begin{array}{l}89.4 \\
39.6\end{array}$ & $\begin{array}{l}52.2 \\
40.4\end{array}$ & $\begin{array}{l}123 \\
51.3\end{array}$ & $\begin{array}{l}80.9 \\
24.0\end{array}$ & $\begin{array}{l}72.6 \\
38.1\end{array}$ \\
\hline Fructose & $\begin{array}{l}0 \\
1.0\end{array}$ & $\begin{array}{l}133 \\
174\end{array}$ & $\begin{array}{l}114 \\
104\end{array}$ & $\begin{array}{c}183 \\
87.2\end{array}$ & $\begin{array}{l}127 \\
66.4\end{array}$ & $\begin{array}{l}181 \\
64.6\end{array}$ & $\begin{array}{l}130 \\
48.7\end{array}$ & $\begin{array}{l}188 \\
23.0\end{array}$ & $\begin{array}{l}151 \\
81.1\end{array}$ \\
\hline Reducing & $\begin{array}{l}0 \\
1.0\end{array}$ & $\begin{array}{l}85.3 \\
94.4\end{array}$ & $\begin{array}{l}77.6 \\
74.1\end{array}$ & $\begin{array}{l}97.5 \\
63.7\end{array}$ & $\begin{array}{l}80.8 \\
65.9\end{array}$ & $\begin{array}{l}97.0 \\
53.1\end{array}$ & $\begin{array}{l}78.1 \\
48.3\end{array}$ & $\begin{array}{l}96.8 \\
33.5\end{array}$ & $\begin{array}{l}87.6 \\
60.4\end{array}$ \\
\hline
\end{tabular}

1 Each figure represents the computed mean of two replicates.

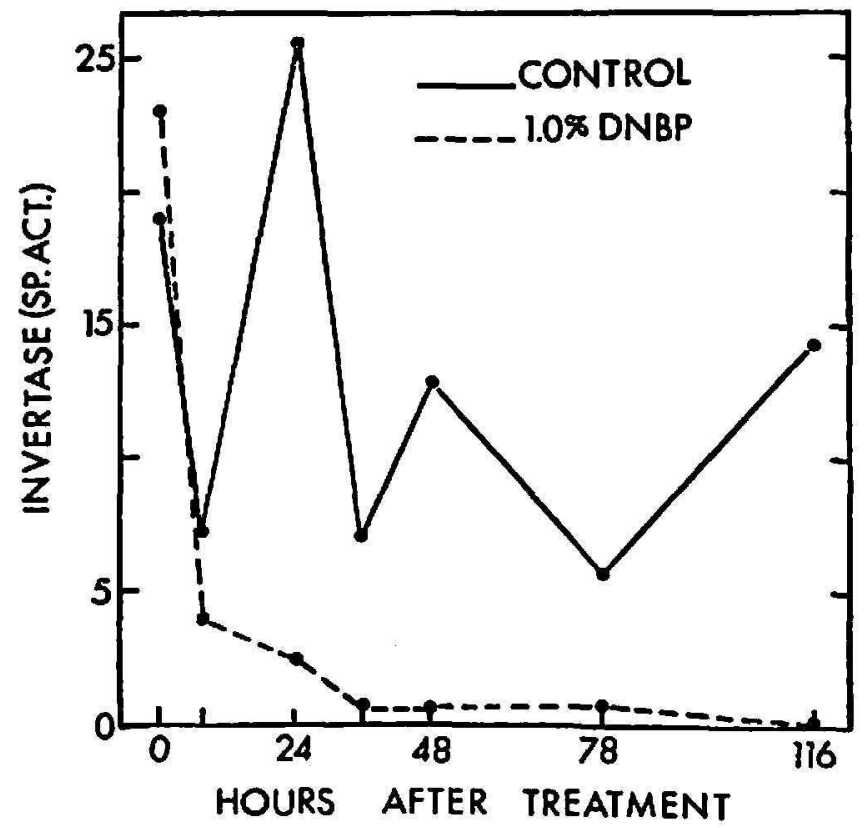

Fra. 9.-Invertase decline in immature storage tissue of sugarcane sprayed with DNBP.

translocation from leaf to immature storage tissue. Again an in vivo achievement of inversion control appears to be nullified by abnormal behavior of other enzymes. 
Amylase was greatly stimulated in immature storage tissue (table 11) and to a lesser extent in leaves (table 12, fig. 10): Increased amylase activity is thus again implicated as a common factor in sucrose losses by desiccated cane. This capability of amylase to alter sucrose level has been recognized for several years $(1,5,6)$ and is discussed at length elsewhere $(10,12,14)$.

TABLE 11.-Specific activity values for immature storage tissue enzymes from sugarcane sprayed with $D N B P^{1}$

\begin{tabular}{l|c|c|c|c|c|c|c|c|c}
\hline \multirow{2}{*}{ Enzyme } & $\begin{array}{c}\text { DNBP } \\
\text { (percent } \\
\text { solution) }\end{array}$ & \multicolumn{7}{c|}{ Hours after treatment } & \multirow{2}{*}{ Mean } \\
\cline { 4 - 7 } Phosphatase & 0 & 22.2 & 19.7 & 21.1 & 18.4 & 17.6 & 21.4 & 20.5 & 20.1 \\
& 1.0 & 27.3 & 17.1 & 23.7 & 21.4 & 23.1 & 23.9 & 24.7 & 23.0 \\
ATP-ase & 0 & 25.0 & 19.9 & 21.2 & 17.1 & 18.5 & 21.1 & 20.8 & 20.5 \\
& 1.0 & 27.3 & 15.9 & 20.8 & 19.8 & 19.3 & 22.7 & 23.9 & 21.4 \\
Amylase & 0 & 67.9 & 50.6 & 64.7 & 56.9 & 60.5 & 49.7 & 44.6 & 57.6 \\
& 1.0 & 80.6 & 76.4 & 135 & 108 & 115 & 120 & 125 & 109 \\
Invertase & 0 & 19.1 & 7.2 & 25.6 & 6.9 & 12.9 & 5.8 & 14.5 & 13.1 \\
& 1.0 & 23.2 & 4.0 & 2.6 & 0.6 & 0.6 & 0.8 & 0 & 4.5 \\
Peroxidase & 0 & 37.4 & 30.4 & 29.4 & 28.7 & 27.5 & 35.9 & 28.9 & 31.2 \\
& 1.0 & 49.1 & 34.5 & 52.6 & 55.7 & 67.6 & 110 & 124 & 70.5 \\
\hline
\end{tabular}

1 Each figure represents the computed mean of two replicates.

TABLD 12.-Specific activity values for leaf enzymes of sugarcane sprayed with DNBP

\begin{tabular}{l|c|c|c|c|c|c|c|c|c}
\hline \multirow{2}{*}{ Enzyme } & $\begin{array}{c}\text { DNBP } \\
\text { (percent } \\
\text { solution) }\end{array}$ & \multicolumn{7}{|c|}{ Hours after treatment } & \multirow{2}{*}{ Mean } \\
\cline { 2 - 7 } & 0 & 8 & 24 & 36 & 48 & 78 & 116 & \\
\hline Phosphatase & 0 & 20.1 & 17.3 & 15.8 & 14.8 & 18.3 & 12.8 & 13.0 & 16.0 \\
& 1.0 & 19.5 & 23.7 & 24.5 & 21.8 & 17.1 & 16.7 & 15.0 & 19.8 \\
ATP-ase & 0 & 28.9 & 25.3 & 22.3 & 24.6 & 26.3 & 20.3 & 18.6 & 23.8 \\
& 1.0 & 22.9 & 38.9 & 31.3 & 28.7 & 22.3 & 17.4 & 13.7 & 25.0 \\
Amylase & 0 & 72.1 & 64.9 & 51.9 & 53.4 & 49.6 & 35.9 & 50.2 & 54.0 \\
& 1.0 & 55.1 & 72.3 & 82.3 & 63.1 & 72.7 & 90.5 & 82.2 & 74.0 \\
Peroxidase & 0 & 111 & 101 & 104 & 127 & 118 & 114 & 119 & 113 \\
& 1.0 & 109 & 158 & 133 & 139 & 194 & 208 & 145 & 155 \\
\hline
\end{tabular}

1 Each figure represents the computed mean of two replicates. 
Suffice it to say that DNBP appears to trigger a sufficient amylase potential to accommodate the glucosidase role suggested above.

The severe blackening of immature storage tissue already mentioned was due probably to abnormally high peroxidase activity (table 11). The enzyme also became more active in leaves following DNBP treatment.
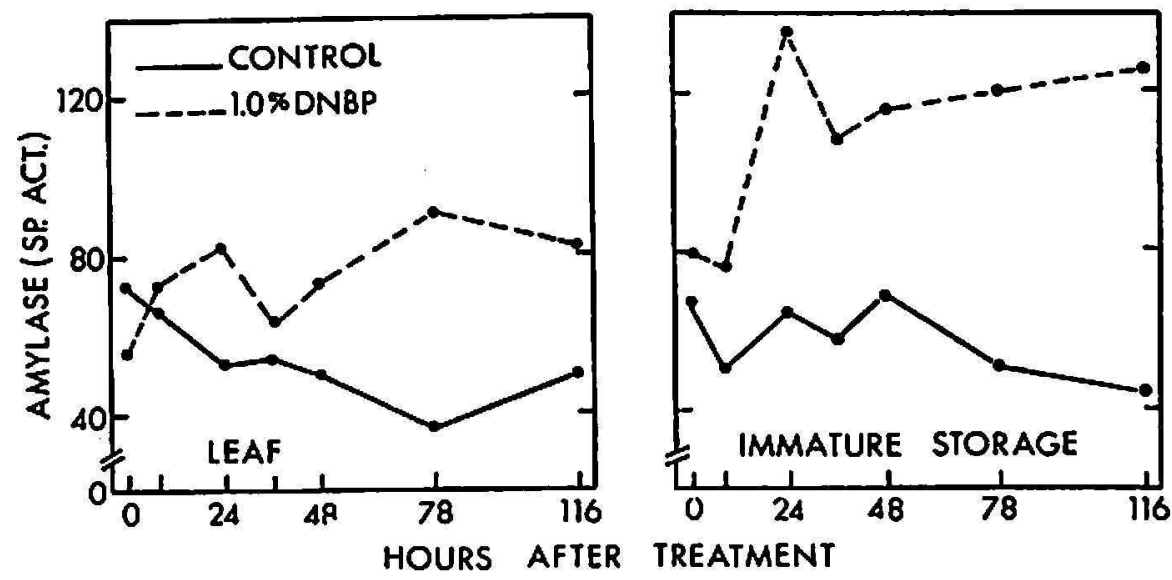

Fic. 10.-Increased amylase activity in leaf and immature storage tissues of sugarcane sprayed with DNBP.

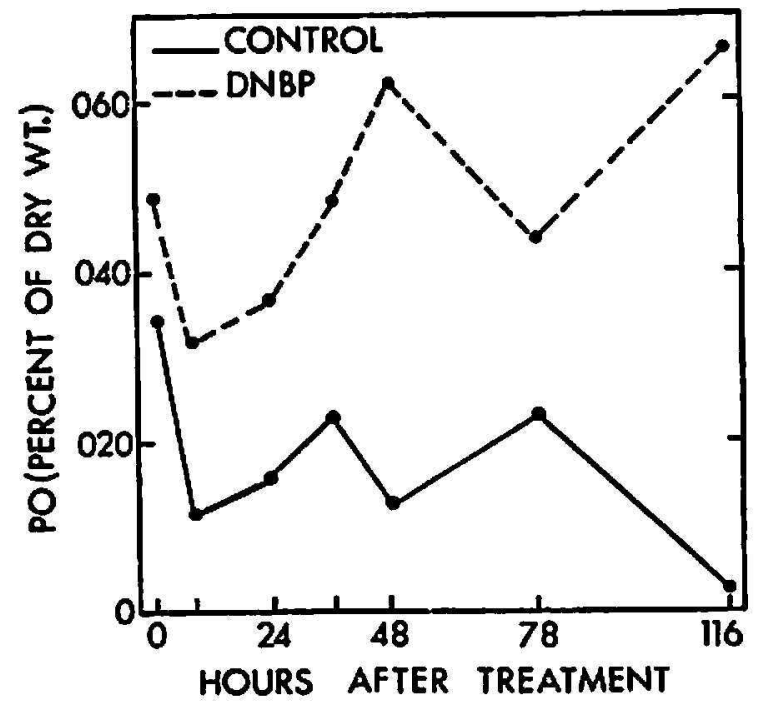

Fra. 11.-Increased organic phosphorus in leaves of sugarcane treated with DNBP.

Neither phosphatase nor ATP-ase was altered consistently by DNBP in either tissue. However, there were very definite increases in leaf organic phosphorus content (fig. 11). This is interpreted as increased synthesis of phosphorylated sugar precursors or metabolites rather than a consequence phosphatase suppression such as that described earlier for Diquat. 


\section{Significance of the effects of Paraquat, Diquat, and DNBP}

Our understanding of what happens to a cane plant when treated with these chemicals, and its significance to the sugar industry, can be summarized as follows:

1. Each chemical can reduce or terminate cane growth and in so doing facilitate the burning of leaves and trash.

2. Each has a valuable potential aside from this, as an in vivo invertase inhibitor. In this capacity the desiccants might eventually be used as ripening agents.

3. This value is negated through loss of photosynthetic activity and nonspecific alteration of sugar-metabolizing enzymes. The latter effect was characterized in our studies by general increases in amylase activity and unpredictable changes in phosphatase, ATP-ase, and peroxidase.

4. The use of desiccants in practice should include control measures against excessive metabolic enzyme activity to retain sucrose already formed. Concurrently, desiccation should be aimed at approaching a photosynthetic cut-off, but some level of sugar synthesis must be maintained to prevent an unfavorable balance of sugar utilization to sugar synthesis.

\section{SUMMARY}

Enzyme behavior and sugar changes were studied in sugarcane treated with the desiccants Paraquat, Diquat and Dinitro-butylphenol (DNBP). The chemicals were applied as foliar sprays to immature cane of the variety P.R. 980 or P.R. 1059 grown in sand culture. There were three objectives: 1, To confirm abnormal enzyme and sugar responses during sugarcane desiccation; 2, to explore enzyme sensitivity within the dimensions of chemical concentration and time; and 3, to determine whether a common pattern of enzyme changes is triggered by the three distinct chemicals.

Paraquat was applied once to P.R. 1059 at levels ranging from 0.0008 to 0.5 percent. All Paraquat treatments quickly wilted foliage. There was little relationship between leaf desiccation and the moisture content of sheaths and stalks, the latter remaining near normal. Leaf sucrose declined sharply to confirm a similar Paraquat effect recorded earlier in P.R. 980. The appearance of ribose in leaf extracts indicates that Paraquat impaired photosynthesis at the level of 0.004 percent and higher. Since desiccation occurred below this level it is suggested that photosynthesis can proceed simultaneously with a limited amount of desiccant action. Evidence was found of Paraquat-induced interconversion of sucrose with raffinose and unidentified sugars. Leaf amylase activity was increased by 0.5 percent Paraquat and all Paraquat levels increased the enzyme in immature storage tissue. Amylase action is believed to account for sucrose decline in spite of a 
severe inhibition of invertase. Leaf peroxidase was greatly suppressed by as little as 0.0008 percent Paraquat, and tyrosinase by higher levels, indicating a sensitivity of cane oxidases to the desiccant.

Diquat, 0.5 percent, was applied to 6-months old P.R. 980 and tissue samples were taken at intervals during the ensuing 144-hour period. Injury symptoms were identical to those of Paraquat. Again, the early desiccation of leaves was not reflected in sheath moisture values. Leaf sucrose was lowered markedly by Diquat within 24 hours but immature storage tissue and stalk juice did not reveal sucrose decline until 96 hours. Ribose was detected by chromatography of leaf extracts. Invertase was severely inhibited. Amylase and peroxidase was stimulated by Diquat in immature storage tissue. Leaf phosphatase and ATP-ase were clearly retarded by Diquat. Their suppression was accompanied by major and persistent increases in leaf organic phosphorus.

Like Diquat, a single 1.0 percent level of DNBP was studied over a prolonged period of time. The chemical was lethal within 8 hours and symptoms are described. Desiccation was generally inferior to that of Paraquat or Diquat. DNBP significantly lowered leaf sucrose within 8 hours. The sucrose decline continued throughout the study and was accompanied by increased reducing sugar content. Chromatography revealed accumulations of fructose and glucose, but no ribose.

Invertase was lowered to an insignificant level within 8 hours after DNBP application. Amylase activity was greatly increased in both leaf and immature storage tissues, apparently denying storage tissues an opportunity to accumulate sucrose. Peroxidase was abnormally high in leaf and immature storage tissues in response to DNBP. Phosphatase and ATP-ase was not affected by DNBP; nevertheless there were definite accumulations of organic phosphorus in DNBP-treated leaves.

Importance of the desiccant-enzyme-sugar relationships to the sugar industry is discussed. It is proposed that these invertase-suppressing chemicals have potential as ripening agents. They are, however, presently too non-specific in their enzyme relationships for full potential to be realized either as desiccants or ripening agents. Amylase and oxidases apparently must be controlled to accumulate or even retain sucrose.

\section{RESUMEN}

Se estudiaron los cambios en el azúcar y el comportamiento de las enzimas en caña de azúcar tratada con los desecantes Paraquat, Diquat y Dinitrobutilofenol (DNBP). Los agentes químicos se aplicaron en forma de aspersión foliar a caña inmadura, cultivada en arena, de las variedades $P$. $R$. 980 6 P. R. 1059. Fueron tres los objetivos: 1, Confirmar la reacción anormal 
de las enzimas y el azúcar durante la desecación de la caña; 2 , explorar la sensibilidad de las enzimas con respecto a la concentración química y al tiempo; y 3, determinar si los tres diferentes agentes inician un patrón común de los cambios enzimáticos.

El Paraquat se le aplicó a la variedad P. R. 980 a concentraciones de 0.0008 a 0.5 por ciento. Todos los tratamientos con Paraquat causaron la rápida marchitez del follaje, pero hubo poca relación entre la desecación de la hoja y el contenido de humedad de la yagua y el tallo, manteniéndose este último casi normal. La sacarosa foliar disminuyó marcadamente, confirmándose asi un efecto similar observado previamente en la variedad P. R. 980. La aparición de ribosa en los extractos de la hoja indica que el Paraquat altera la fotosíntesis a concentraciones de 0.004 por ciento o más. Como la desecación ocurrió a una concentración más baja, parece ser que la fotosíntesis puede proseguir simultáneamente con una acción limitada del desecante. Se evidenció cierta interconversión entre la sacarosa y la rafinosa y otros azúcares no identificados, inducida por el Paraquat. El Paraquat al 0.5 por ciento aumentó la actividad de la amilasa foliar, y a todas las concentraciones, la de la enzima en el tejido reservante tierno. Se cree que la acción de la amilasa es la causa de la disminución de la sacarosa a pesar de una severa inhibición de la invertasa. La peroxidosa foliar fue grandemente suprimida por una concentración de hasta 0.0008 por ciento de Paraquat, y en el caso de la tirosinasa por concentraciones más elevadas, indicando la sensibilidad de las oxidasas de la caña al desecante.

El Diquat, al 0.5 por ciento, se le aplicó a la variedad P.R. 980 de 6 meses de edad, tomándose muestras de los tejidos a intervalos durante el siguiente período de 144 horas. Los síntomas de las lesiones causadas eran idénticos a los del Paraquat. Una vez más la desecación inicial de las hojas no se reflejó en los valores de humedad de la yagua. El Diquat bajó marcadamente la sacarosa foliar dentro de las 24 horas, pero el tejido reservante tierno y el jugo del tallo no revelaron disminución en el contenido de sacarosa hasta 96 horas después. La ribosa fue identificada mediante la cromatografía de los extractos de las hojas. La invertasa fue severamente inhibida. La amilasa y la peroxidasa fueron estimuladas por el Diquat en el tejido reservante tierno. La fosfatasa de la hoja y la ATP-asa fueron evidentemente retardadas por el Diquat. La supresión de éstas fue acompañada por aumentos mayores y persistentes en el fósforo orgánico foliar.

Al igual que el Diquat, se estudió por un tiempo prolongado la acción del DNBP al 1.0 por ciento. El desecante fue letal dentro de 8 horas, describiéndose los síntomas, y la desecación fue generalmente menos efectiva que la del Paraquat y el Diquat. El DNBP bajo significativamente la sacarosa foliar dentro de las 8 horas. La disminución de sacarosa continuó durante 
todo el estudio y fue acompañada por un aumento en el contenido de azácares reductores. La cromatografia reveló acumulaciones de fructosa y glucosa, pero no de ribosa.

La invertasa bajó a un nivel insignificante dentro de las 8 horas posteriores a la aplicación del DNBP. La actividad de la amilasa aumentó grandemente tanto en la hoja como en los tejidos reservantes tiernos, impidiendo asi, aparentemente, que el tejido reservante acumulara sacarosa. El contenido de peroxidasa en la hoja y en los tejidos reservantes tiernos fue anormalmente elevado por efecto del DNBP. La fosfatasa y la ATP-asa no fueron afectadas por el DNBP; sin embargo, hubo acumulaciones definidas de fósforo orgánico en las hojas tratadas con DNBP.

Se discute la importancia que tienen para la industria azucarera las relaciones entre los desecantes, las enzimas y el azúcar. Se propone que estos agentes químicos supresores de la invertasa tienen un potencial como agentes que afectan la madurez. Sin embargo, todavia no son lo suficientemente especificas las relaciones enzimáticas para percibir su potencial total como desecantes o como agentes que afecten la madurez. La amilasa y las oxidasas aparentemente deben controlarse para que puedan acumular 0 aun retener la sacarosa.

\section{LITERATURE CITED}

1. Alexander, A. G. Sucrose-enzyme relationships in immature sugarcane as affected by variable nitrate and potassium supplied in sand culture, J.Agr. Univ. P.R. 48 (3): 165-231, 1964.

2. - Hydrolytic proteins of sugarcane. The acid phosphatases, J. Agr. Univ. P.R. 49 (2): 204-28, 1965.

3. - Hydrolytic proteins of sugarcane. The acid invertases, J. Agr. Univ. P.R. 49 (3): 287-307, 1965.

4. - Hydrolytic proteins of sugarcane. Amylase, J. Agr. Univ. P.R. 49 (3): 308-24, 1965.

5. - Behavior of enzymes governing starch and sucrose forming pathways in two sugarcane varieties supplied with variable nitrate and phosphate in sand culture, J. Agr. Univ. P.R. 49 (1): 60-75, 1965.

6. - The biosynthesis of starch in sugarcane, Proc. XII Cong. Int. Soc. Sugar Cane Technol. pp. 625-38, 1965.

7. - Induction of varying sugar levels in leaves of immature sugarcane by use of acid phosphatase inhibitors, J. Agr. Univ. P.R. 49 (1): 35-59, 1965.

8. - - Oxidizing enzymes of sugarcane. Peroxidase, J.Agr. Univ. P.R. 50 (1): 36-62, 1966.

9. - - Oxidizing enzymes of sugarcane. Tyrosinase, J. Agr. Univ. P.R. 50 (2): 113-30, 1966.

10. - High sucrose levels and abnormal enzyme activity as a function of nutritional stress in sugarcane, J. Agr. Univ. P.R. 51: (4): 325-33, 1967.

11. - Action patterns of sugarcane acid invertase, J. Agr. Univ: P.R. 61 (2): 154-66, 1967. 
12. - The potential of sugarcane to produce sucrose, Proc. XIII Int. Soc. Sugar Cane Technol., Taiwan, 1968.

13. - Relationships of gibberellic acid to water and phosphorus in the growth, sugar production, and enzyme behavior of sugarcane, J. Agr. Univ. P.R. 63 (3): 149-66, 1969.

14. - and Samuels, G., Controlled-temperature studies of growth, enzymology, and sucrose production by two sugarcane varieties in Puerto Rico, J. Agr. Univ. P.R. 68 (3): 204-17, 1968.

15. - In vitro effects of silicon on the action patterns of sugarcane acid invertase, J. Agr. Univ. P.R. 6\& (4): 311-22, 1968.

16. - and Montalvo-Zapata, R., Enzyme studies of sucrose decline in sugarcane desiccated with Paraquat, J. Agr. Univ. P.R., 58 (4): 230-250, 1969.

17. Cardini, C. E., Leloir, L. F., and Chiriboga, J., The biosynthesis of sucrose, $J$. Biol. Chem. 214: 149-55, 1955.

18. Dube, S. K., and Nordin, P., Isolation and properties of sorghum alpha-amylase, Arch. Biochem. and Biophys. 94: 121-7, 1961.

19. Roe, J. R., A colorimetric method for the determination of fructose in blood and urine, J. Biol. Chem. 107: 15-22, 1934.

20. Sumner, J. B., Dinitrosalicylic acid: A reagent for estimation of sugar in normal and diabetic urine, J. Biol. Chem. 47: 5-9, 1921.

21. Sutherland, E. W., Cori, C. F., Haynes, R., and Olsen, N. S., Purification of the hyperglycemic-glycogenolytic factor from insulin and gastric mucosa, $J$. Biol. Chem. 180: 825-37, 1949. 